Boise State University ScholarWorks

Community and Regional Planning Faculty

Publications and Presentations

Department of Community and Regional Planning

11-1-2014

\title{
The Impact of Telecommuting on Personal Vehicle Usage and Environmental Sustainability
}

Pengyu Zhu

Boise State University

Susan G. Mason

Boise State University 


\title{
The Impact of Telecommuting on Personal Vehicle Usage and Environmental Sustainability
}

\author{
Pengyu Zhu \\ Department of Community and Regional Planning \\ Boise State University \\ Susan G. Mason \\ Department of Community and Regional Planning \\ Boise State University
}

\begin{abstract}
To understand whether telecommuting could be part of the policy solutions for greenhouse gas reduction in the transportation sector, this study uses Instrumental Variable Tobit models and data from 2001 and 2009 National Household Travel Surveys to explore whether telecommuting reduces or increases the daily work and non-work vehicle miles traveled. Our findings suggest telecommuters have more vehicle miles traveled for both daily work and non-work trips than non-telecommuters. Adding the findings that telecommuting has no impact on other non-working household member's daily total (nonwork) trips, we can possibly argue that households with telecommuter(s) tend to have higher daily total vehicle miles traveled. Our estimated marginal effect of telecommuting on worker's daily total trips indicates that, a telecommuter on average travels 38 vehicle miles more on a daily basis in 2001 and 45 vehicle miles more in 2009 compared with a non-telecommuter. These increases in vehicle miles traveled translate into a rather large increase in greenhouse gas emissions in the U.S. equivalent to adding 7,248,845 cars in 2001 and 8,808,165 in 2009 to the road. Moreover, the difference of this marginal effect between 2001 and 2009 suggests the impact of telecommuting on worker's daily total vehicle miles traveled had increased over time. With the emerging work arrangements to work from home, telecommuting has been welcomed in this changing environment, not only by individual workers and employers but also policymakers. But the outcomes seem to be opposite to what policy makers may have expected for GHG emission reductions.
\end{abstract}

Keywords: Greenhouse Gas; Sustainability; Telecommuting; Vehicle Miles Traveled

\section{Introduction}

\section{Background and Research Objectives}

Changes in individuals' travel behavior along with improvements in technology that foster fuel efficiency and the use of alternative fuels provide the most promise for reducing greenhouse gas (GHG) emissions (Santos et al., 2010; Urban Land Institute, 2009). Despite the increasing awareness of the impacts of climate change, GHG emissions continue to be high. National indicators reveal total GHG emissions climbed from 6,182 million metric tons of carbon dioxide equivalent $\left(\mathrm{MMTCO}_{2} \mathrm{e}\right)$ in 1990 to 6,633 $\mathrm{MMTCO}_{2} \mathrm{e}$ in 2009. Carbon Dioxide accounted for 82 percent of the GHG generation. Energy consumption is the largest producer of carbon dioxide $\left(\mathrm{CO}_{2}\right)$ generating 5,168 million of the 6,633 $\mathrm{MMTCO}_{2} \mathrm{e}$ in the U.S. in 2009. Nationally, energy consumption is broken down by sector (i.e., transportation, industry, residential and commercial buildings). The transportation sector generates the most GHG emissions by fossil fuel consumption of all of the sectors, accounting for 33 percent of all energy consumption and energy related GHG emissions annually in the U.S., (U.S. Environmental Protection Agency (EPA)a 2011, pp. ES 2-9).

Although GHG emissions peaked in 2007 and then dropped by 1,020 $\mathrm{MMTCO}_{2} \mathrm{e}$ in 2009 the overall reduction in GHG emissions can be contributed mostly to decreasing output in the economy and subsequent reduction in energy consumption as well as the decreasing use of fossil fuels in generating electricity as the price of natural gas decreased (EPAa, 2011). In the transportation sector, the U.S. EPA notes: 
This is an author-produced, peer-reviewed version of this article. The final, definitive version of this document can be found online at International Journal of Environmental Science and Technology, published by Springer. Copyright restrictions may apply. doi: $10.1007 /$ s13762-014-0556-5

Virtually all of the energy consumed in [the transportation] end user sector came from petroleum products. Nearly 65 percent of the emissions resulted from gasoline consumption for personal vehicle use.... From 1990 to 2009, transportation emissions rose by 16 percent due, in large part, to increased demand for travel and the stagnation of fuel efficiency across the U.S. vehicle fleet. The number of vehicle miles traveled by light-duty motor vehicles (passenger cars and light-duty trucks) increased 39 percent from 1990 to 2009, as a result of a confluence of factors including population growth, economic growth, urban sprawl, and low fuel prices over much of this period (U.S. EPAa 2011, p. ES8).

This suggests very little of the reduction in GHG gases had to do with people changing their behaviors by changing their means of transportation to work, for example.

If scientists are correct and global temperatures rise anywhere between 1.39 and 5.56 degrees Celsius this century due to increased GHG emissions, then the potential value of reducing the 1,724 $\mathrm{MMTCO}_{2} \mathrm{e}$ generated by transportation users is significant (U.S. Environmental Protection Agency (EPA)a 2011, pp. ES 2-9). This is especially true in the area of transportation where the U.S. EPA estimates one-gallon of gas used generates about 8,887 grams $\mathrm{CO}_{2}$. The EPA indicates that in 2012 the average light-duty motor vehicle maintained a fuel use of 23.8 miles per gallon (U.S. EPA, 2013, p A-17). Using EPA's formula for estimating annual $\mathrm{CO}_{2}$ emissions results in the average passenger car driver generating 4.5 metric tons of $\mathrm{CO}_{2}$ in 2012 (U.S. EPAb, 2011, pp. 12).

President Obama's challenge to automakers to increase passenger vehicle gas mileage to 54.5 miles per gallon by 2025 (New York Times, 2011) is certainly one way to begin tackling the matter and reducing GHG emission and our dependency on foreign oil simultaneously. Another formidable way would be to reduce overall travel by encouraging people to change their driving habitats and use more transit options, carpooling, and telecommuting opportunities.

This article focuses on the extent to which changes in individual travel behavior, specifically the impact of telecommuting could have on GHG reduction. A few studies have focused on the value of the built environment to promote telecommuting (Tang et al. 2011; Winkelman et al. 2009). Some studies have even examined the relationship between information and communication technologies on travel behavior or urban development (Coroama et al. 2012; and Buliung, 2007; Tayyaran and Khan, 2003). Other scholars have begun to quantify household carbon footprints including detail on the modal shifts in passenger transportation and the effect on energy related impacts to both buildings and transportation options with a shift to working at home instead of the office (Roth et al. 2008; Cuernot et al. 2012; Jones and Kammen, 2011; Fuhr and Pociask, 2011; Kitou and Horvath, 2008; Kitou and Horvath, 2003a). Indirect effects of telecommuting such as office space not built, office space energy not consumed, and the impact on congestion or finances not spent on infrastructure as the result of telecommuting have all been estimated. While the benefits of telecommuting have been noted by scholars, as discussed below, other studies suggest a re-bound effect for telecommuting. That is to say the total mileage not traveled to work may be offset by errands or other trips previously made during a person's typical commute with trip-chaining. Another alternative explanation for the rebound effect is that teleworkers may live further out so the gains from telecommuting (i.e. less frequent commuting) could be offset by longer commute distances (when they do commute) and longer non-work travel such as leisure trips (Zhu 2011, 2012, 2013; Holden and Linnerud, 2011; Fuhr and Pociask, 2011). Even though telecommuting is just one individual behavior change that may affect GHG emissions, in reviewing the literature it appears none of the scholarship has explicitly estimated the potential impact of telecommuting on the total amount of GHG emissions in the U.S.

To understand the way telecommuting could be part of the solution or problem for GHG reduction in the transportation sector, this research examines the way telecommuting affects vehicle miles traveled (VMT) and the resulting potential change in GHG emissions. Specifically, this study looks at data from the U.S. National Household Travel Surveys (NHTS) to run analysis on the daily VMT by telecommuters and non-telecommuters. Our models address two empirical challenges: 1) use Tobit model to take into account samples with 0 VMT; 2) use Instrumental Variable approach to address the endogeneity issue associated with the choice of telecommuting. We also estimate the marginal effects of telecommuting on work trip VMT and non-work trip VMT. The study then uses a methodology developed by the EPA to estimate the impact on GHG emissions. We hypothesize that more telecommuting will not necessarily generate fewer GHG emissions because of the rebound effects mentioned previously. Although there may be many other benefits to telecommuting, GHG reduction may not be one of them. The article concludes with a call for a holistic measurement of policy outcomes targeted toward the reduction of GHG emissions as opposed to less direct measures such as VMT. 
This is an author-produced, peer-reviewed version of this article. The final, definitive version of this document can be found online at International Journal of Environmental Science and Technology, published by Springer. Copyright restrictions may apply. doi: $10.1007 /$ s13762-014-0556-5

Finally, directions for further research are discussed.

Literature review

\section{1) Benefits of telecommuting}

The benefits of telecommuting have been touted by many. They include improved economic productivity due to reduction in travel time to work and increasing the number of jobs that can be accessed by people (Cox, 2009). Scholars estimate that 45 percent of the U.S. workforce holds jobs compatible with at least part-time telework which has implications for GHG reduction. It is projected that if telecommuters worked at home just 2.4 days a week GHG could be reduced by 51 million metric tons of $\mathrm{CO}_{2} \mathrm{e}$. Even the energy saved directly from telecommuting has the potential to exceed the output of all renewable energy sources combined (Lister and Harnish, 2011). Additionally, telecommuting has zero emissions and there is evidence it can reduce daily trips from 51 percent to 77 percent (Balaker, 2005). Fuhr and Pociask (2011) reviewed the literature and found employees and employers benefit as well. Some of the benefits employees reported include job flexibility which can enhance their balance between work and personal time, having a distraction free environment, better time management, fewer office politics concerns, less stress as well as gas savings and lower care maintenance cost (pp. 42-43). The literature indicates that employers also reported benefits from telecommuting, including gains in productivity, reduced absenteeism, decreases in turnover rate, and less needs for equipment, office space, and parking. The use of home office energy was also reported to be lower than that in commercial space (pp. 43-44). Additionally, Fuhr and Pociask found literature supporting benefits to society with reduced infrastructure needs and automobiles accidents, decreased pollution and increases in the quality of life of elderly and disabled persons and increases in labor force participation for these same individuals. Finally, home-shoring is another reported societal benefit where jobs that would have been shipped overseas are now harbored at U.S domestic homes, for example home-based agents for companies such as JetBlue (p. 44). In combination these factors may be increasing quality of life of telecommuters.

Other scholars have found more nuanced benefits where transportation impacts could be lessened by telecommuting, but home-related impacts may not be reduced if office space is shared, for example (Kitou and Horvath a, 2003, 3467). Matthews and Williams (2005) investigated telework and energy use in buildings in the U.S. and Japan found the energy savings to be very modest compared to other public available ways to mitigate energy use. Yet the authors caution if trends in telecommuting grow, more attention may be warranted to the energy savings that could accrue from office building use.

\section{2) Factors of influence for outcomes in telecommuting}

When examining the influence of the built environment on the likelihood to telecommute Tang et al. (2011) found factors that affect working at home to be nuanced by the frequency one telecommutes. This makes a particular attribute for telecommuting more attractive to some people than others. In general, and a somewhat surprising finding was that individuals with positive views about transit were more likely to work at home. This was the case also for individuals who viewed driving negatively. Additionally, persons with pro-bicycling attitudes were also more likely to telecommute (p.17). These findings suggest that an increase in telecommuting might not result in a reduction of vehicle miles traveled for all telecommuters.

Khan (2010) also finds there are considerations that cause some people to be more receptive to telecommuting such as access to broad-band networks, traffic-congestion, and employer initiated telecommuting programs. Finally, employee and employer preferences for telecommuting revealed employees find telecommuting most favorable when the employer provides the equipment, their commute distance is longer than average, their vehicle has lower than average fuel efficiency, they highly value their travel time, and they can telecommute frequently. Employers on the other hand found telecommuting most advantageous when the telecommuter bears the equipment cost, there is low telecommuter turnover, the telecommuting employee is highly productive, and telecommuting is frequent (Shafizadeh et al., 2007).

Holden and Linnerud (2012) point out indirect market based incentives can result in subsidizing public transportation which can have unintended consequences such as shifting one's mode use from bicycling to using transit (p. 3090). Another example the authors provide is that more fuel efficient cars may encourage more driving. In terms of leisure travel specifically, they find $\mathrm{CO}_{2}$ emissions are not altered by policies intended to reduce emissions. The authors conclude this is the case because the policies are not actually intended to reduce $\mathrm{CO}_{2}$ emissions but rather target everyday transportation choices that may result in substitution effects that increase other types of travel activity. 
This is an author-produced, peer-reviewed version of this article. The final, definitive version of this document can be found online at International Journal of Environmental Science and Technology, published by Springer. Copyright restrictions may apply. doi: 10.1007/s13762-014-0556-5

Some scholars argue for a more holistic approach to understanding, studying and integrating policies to promote sustainable transportation options. Specifically, Santos et al. (2010) find that is necessary to consider policies dealing with the physical environment, as well as polices that reduce congestion and emissions such as car sharing and telecommuting along with policies that promote research and development of new low carbon technologies in the transportation sector. The authors argue the pursuit of the trinity of these policies in tandem creates synergies that encourage sustainable transportation.

Moos et al. (2006) focuses on the implications of telework offering an approach to conduct a more complete assessment of benefits and offsets derived from telecommuting. The authors' method of measuring one's ecological footprint makes it possible to capture the energy related substitution effects and determine a net difference in GHG emissions from a particular policy. While their qualitative tool has the capacity to capture the range of outcomes in a policy, one drawback is its descriptive nature lacks the details to identify causality or metrics on trips and motivators for telecommuting that planners and policymakers seek for policy adaption, implementation, and evaluation (Moos et al., 2006, pp. 11-12).

As previously noted several studies have found telecommuters may drive more than non-telecommuters or are at least tempted to do so because they have the time (Marletta et al. 2004; and Buliung 2007). Attempts to more systematically understand the complex network of choices and the outcomes from individual decisions (such as Santos et al. trinity of policies) may shed light on any rebound effects that could negatively impact the potential telecommuting may have for GHG reduction. One example is McCollum and Yang's (2009) scenario analysis tool which estimates the variation in transportation outcomes for the variety of motorized transportation options can help determine impact of choices on future energy use.

Coroama et. al (2011) investigate the substitution effect by specifically looking at video conferencing as a replacement for work related travel. The authors find overall $\mathrm{CO}_{2}$ emissions are reduced significantly and even substantially enough to compensate for rebound effects (p. 10). This has potential ramifications for a significant reduction in GHG due to reduced transportation via aviation. Yet the author provides fair warning against making estimations for the reduction of global emission levels. The author is cautious about making global estimates due to a lack of data available to determine the actual number conferences that could successfully use internet-based multi-site conferencing in lieu of face-to-face meetings that may require air travel.

The literature reveals that telecommuting has the potential to impact and reduce GHG emissions derived from the use of light duty cars and trucks. It is for this reason we rely on the change in passenger car VMT to estimate effects of telecommuting on $\mathrm{CO}_{2}$ emissions. However, before we can even look at the impact of telecommuting on GHG emissions, we must first calculate the impact of telecommuting on VMT.

\section{Materials and methods}

\section{Data and definitions}

This study uses data from the 2001 and 2009 NHTS in the U.S. The NHTS collected information on the characteristics and location of households, socioeconomic status of household members, and the status of telecommuting for workers. In addition, the surveys in both years used a one-day trip diary to record all trips made by the respondent on a randomly assigned travel day. According to the trip diary, trips can be classified into work trips and non-work trips. Daily work trips can be further decomposed into "to/from work" trips and "work related business" trips. Based on NHTS definition, "to/from work" trips, which might include trips for lunch, break, etc., are not identical to commuting trips. Daily non-work trips include shopping trips, other family/personal business trips, school/church trips, medical/dental trips, visit friends/relatives trips, and other social/recreational trips.

Telecommuters are defined as workers who work at home instead of going to their usual workplace for at least once a week. In addition to those who never telecommute, infrequent telecommuters are also defined as nontelecommuters, as infrequent telecommuting (e.g. once a month) would have limited effect on the respondent's residential location choice, travel behavior, and thus VMT.

Preliminary comparisons in Table 1 show some clear differences between telecommuters and nontelecommuters. When workers with 0 VMT in each trip category are excluded in calculating the means, nontelecommuters are traveling fewer vehicles miles for work than telecommuters in both 2001 and 2009. Given that the survey day for the one-day trip diary is randomly selected, it is possible that a telecommuter is not 
This is an author-produced, peer-reviewed version of this article. The final, definitive version of this document can be found online at International Journal of Environmental Science and Technology, published by Springer. Copyright restrictions may apply. doi: $10.1007 / \mathrm{s} 13762-014-0556-5$

telecommuting on that day. By excluding those cases with 0 VMT, the analyses would have omitted the very people for whom telecommuting has the greatest impact on VMT, and possibly the greatest environmentally beneficial impact. For example, if the 1,695 telecommuters (in the 2001 NHTS sample) who have 0 work trip VMT on the diary day are included in the average, and similarly for the 27,690 non-telecommuters who have no work trip VMT, the difference between telecommuters and non-telecommuters shrinks considerably: 27.2 VMT for non-telecommuters compared to 37.3 VMT for telecommuters (in the first section of Table 1) becomes 16.1 versus 18.0 when 0 VMT cases are included (in the second section of Table 1)-which might be insignificant in a model that controls for income, occupation, location, etc. Therefore, we apply left-censored Tobit models to take into account these censored cases. For non-work trips, telecommuters have significantly longer VMT than non-telecommuters in both years, with or without including those cases with 0 non-work trip VMT.

[Table 1 about here]

Model specification

The baseline model follows the activity-based approaches (Fox 1995) and attributes travel demand to socioeconomic status, demographic factors including household structure, lifecycle and lifestyle (see for example, Strathman, Dueker and Davis 1994; Nelson and Niles 2000; Srinivasan and Ferreira 2002; Zhu 2012). The specification follows an Ordinary Least Squares (OLS) model:

Trip VMT $=f$ (vector of demographic and socioeconomic characteristics, vector of locational attributes, vector of transportation factors, telecommuter dummy)

The dependent variable is the daily trip VMT for different trip purposes (e.g., work trips, non-work trips). The explanatory variables include individual demographic characteristics (gender, age, education, occupation), household socioeconomic characteristics (presence of child, household income), locational attributes (MSA size, place of residence in urbanized area, suburban area or rural area), and transportation characteristics (number of vehicles per driver in the household, trip day is weekend or not). Our variable of interest is the telecommuter dummy variable.

In order to fully understand the impact of telecommuting on daily trip VMT, we study the VMT using privately owned vehicles by both workers and non-workers. For workers, we investigate how telecommuting affects their daily work trip VMT, daily non-work trip VMT, and daily total trip VMT. We also decompose daily work trips and daily non-work trips into the various categories we mentioned earlier. For non-workers, we focus on their daily total (non-work) trip VMT as well as those decomposed non-work trip categories. Table 2 provides summary statistics for our dependent variables and explanatory variables.

[Table 2 about here]

However, this baseline model suffers two potential biases. First, as indicated earlier, the analyses of the travel impact of telecommuting would be biased because, by excluding those cases with 0 VMT, we omitted the very people for whom telecommuting has the greatest impact. Theoretically, this bias would apply to the analyses of both work trips and non-work trips. Telecommuters are less likely to have work related VMT on days they telecommute; but they are also more likely to have non-work trip VMT on those days they do not have to go to their workplace. This problem could be solved by using left-censored Tobit model to include those 0 VMT cases.

The second bias applies to the analyses of work trips. When studying "to/from work" trip VMT, there exists an endogeneity problem associated with the telecommuter variable. A worker's choice to telecommute is endogenous to commute distance. It is possible that a worker chooses to commute longer because he/she can telecommute, or the other way around, that longer commutes give the worker incentives to telecommute to avoid lengthy commutes. The commuting trips account for a major portion of daily "to/from work" trip VMT. ${ }^{1}$ In this sense, the likelihood of telecommuting could also be reversely affected by the daily "to/from work" trip VMT, as longer commuting trips might cause a worker to choose to telecommute. That is, the telecommuter variable might be endogenous when studying the daily "to/from work" trip VMT. In order to address this potential endogeneity problem when analyzing the daily "to/from work" trip VMT, we use an Instrumental Variable approach to adjust the left-censored Tobit model, by adding instrumental variables to instrument the telecommuter variable. The instrumental variables used in the 2001 2SLS models are internet use at home (dummy) and total number of phones available; the instrumental variable used in the 2009 2SLS models is

${ }^{1}$ Note that “to/from work" trips include commuting trips, lunch trips, and other trips such as coffee breaks. 
This is an author-produced, peer-reviewed version of this article. The final, definitive version of this document can be found online at International Journal of Environmental Science and Technology, published by Springer. Copyright restrictions may apply. doi: $10.1007 / \mathrm{s} 13762-014-0556-5$

"frequently use internet" (dummy), due to changes in the 2009 NHTS questionnaire. These instrumental variables affect worker's likelihood of telecommuting, but do not directly [emphasis added] affect his/her commute distance (and in turn daily "to/from work" trip VMT). They may do so only indirectly, through their impact on the choice of telecommuting. This reason makes these variables viable instruments for the telecommuter variable. In addition, when analyzing worker's daily total work trip VMT and work related business trip VMT, we also test the Instrumental Variable Tobit models for endogeneity bias.

When studying worker's daily total non-work trip VMT, the telecommuter variable could be treated as exogenous. Conceptually, worker's daily non-work trip VMT does not affect the likelihood of telecommuting. Longer commuting trips might cause a worker to choose to telecommute, but longer non-work trips will arguably have no direct impact on a worker's choice to telecommute. Indeed, based on Durbin-Wu-Hausman chi-sq test, the "difference-in-Sargan" test, and the Wald test for exogeneity, it is suggested that the telecommuting variable be treated as exogenous in the models for worker's daily total non-work trip VMT and the various sub-categories of non-work trips. Therefore, these analyses use left-censored Tobit models.

\section{Calculating GHG emissions changes due to telecommuting}

We use the EPA formula for calculating GHG emissions and 2010 U.S. Census data on employment. The formula and census data allows us to estimate from the resulting VMT findings for all telecommuters and the resulting impact on $\mathrm{CO}_{2}$ emissions. In our calculation of the effect of telecommuting on $\mathrm{CO}_{2}$ emissions we assume no major change in technology from the 1990s as did in McCollum and Yang (2011, p. 5583). This is warranted as there is little reason to alter the status quo on the calculation because there is no evidence of significant changes in technology or fuel sources in the mass market since the 1990s. We do incorporate improvements in vehicle gas mile between the two years as calculated by the EPA. Although we cannot know substitution effects on aviation or bus travel by simply calculating VMT for telecommuters, we can at least acquire a direct estimate of the impact of telecommuting on $\mathrm{CO}_{2}$ emissions given the telecommuters VMT.

\section{Results and discussion}

\section{Work Trips}

1) Instrumental Variable Tobit Model Results

Table 3 presents Instrumental Variable Tobit model results for the daily total work trip VMT, to/from work trip VMT, and work-related business trip VMT in 2001 and 2009. Models (1) through (3) in Table 3 present results for 2001, while Models (4) through (6) report results for 2009.

[Table 3 about here]

Of particular interest is the role of telecommuting in affecting worker's daily work trip VMT. The models show consistent results for 2001 and 2009. Models (1) and (4) show significant positive impact of telecommuting on workers' daily total work trip VMT in both 2001 and 2009, suggesting that on a daily basis, those workers with a telecommuting option tend to drive more for job related purposes than those without such an option. ${ }^{2}$ After decomposing daily total work trip VMT into two sub-categories (to/from work trip VMT and work related business trip VMT), we found telecommuting had a statistically significant and positive effect on both categories in both 2001 and 2009. Note that these results were found after controlling for workers' demographic and household characteristics as well as location attributes.

Since we estimate the same models for 2001 and 2009, it is possible to compare the impact of telecommuting on daily work trip VMT over the years. In terms of the impact of telecommuting on daily total work trip VMT, the models show that the coefficient estimate for telecommuter increase from 69.5 in 2001 (Model 1) to 88.9 in 2009 (Model 4). When decomposing daily total work trip VMT into to/from work trip VMT and work related business trip VMT, we still see the impact of telecommuting increases over the years. For total to/from work trip VMT, the models show that the coefficient estimate for telecommuter changes from 24.1 in 2001 (Model 2) to 73.5 in 2009 (Model 5); for total work related business trips, the impact of telecommuting increases from 374.6 in 2001 (Model 3) to 428.6 in 2009 (Model 6). Overall, these results indicate that the size of the impact of

\footnotetext{
${ }^{2}$ We use the term "workers with a telecommuting option" to emphasize the fact that some telecommuters did not telecommute on the day of the trip diary.
} 
This is an author-produced, peer-reviewed version of this article. The final, definitive version of this document can be found online at International Journal of Environmental Science and Technology, published by Springer. Copyright restrictions may apply. doi: $10.1007 /$ s13762-014-0556-5

telecommuting on daily total work trip VMT has increased over the years, suggesting that telecommuters have chosen to drive more for job related purposes over this time period, to an extent that is larger than those nontelecommuters.

Among worker's demographic characteristics, male workers consistently report significantly longer daily total work trip VMT in both years (specifically, both longer to/from work trip VMT and longer work related business trip VMT). Older workers and workers with medical condition tend to have shorter daily work trip VMT. We also find that workers with higher education generally have longer daily work trip VMT. With respect to the respondent's occupation, we find that, in both 2001 and 2009, workers have the longest daily total work trip VMT if working in the categories of "manufacturing, construction, maintenance, or farming", followed by occupations in "professional, managerial, or technical" and then "Clerical and administrative support" (omitted category in our models). Workers in the category of "sales or service" tend to have the longest work related business trip VMT in both years.

Among household socioeconomic attributes, workers in households with higher total income and greater number of vehicles per driver tend to have longer daily total work trip VMT in both years (specifically, both longer to/from work trip VMT and longer work related business trip VMT). Whether the household has children did not play an important role in affecting daily work trip VMT. Among household location characteristics, we note that workers residing in the suburbs (omitted category in the models) tend to have longer daily total work trip VMT than those living in urbanized areas in both years. We also see a pattern that daily total work trip VMT increase with the population size of MSA in 2001 and 2009.

\section{2) Other Tests}

The Instrumental Variable Tobit models address the endogeneity bias and provide more plausible estimates for the instrumented telecommuter variable. Since weak or invalid instruments will lead to measurement errors in the endogenous regressor (Bound et al. 1995; Hall et al. 1996; Greene 1997; Staiger and Stock 1997), we conduct the IV redundancy test, the Bound-Jaeger-Baker F test (see Bound et al., 1995), and the "partial R2" test (see Shea 1997) on the relevance of these instruments after running the first stage regressions for both 2001 and 2009. ${ }^{3}$ All these tests suggest that the selected instruments are relevant for the models.

To provide some corroboration for the VMT impact of telecommuting, we also test OLS models (see models 1 ) and 3) in Appendix 2) that only consider those non-0 VMT cases to examine whether telecommuting still has a positive impact on VMT if we only include workers who actually made work related travel by car on the survey day. In addition, we test Two-Stage Least Square (2SLS) models (see models 2) and 4) in Appendix 2) to address the endogeneity bias when we study these non-0 VMT cases. Both OLS and 2SLS models provide further evidences that telecommuters consistently have longer daily work trip VMT when compared with nontelecommuters. Note that the OLS models and 2SLS models use the natural log of VMT as the dependent variable for the sake of model goodness of fit. Thus, their coefficient estimates are not directly comparable to those in Instrumental Variable Tobit models. But comparing the OLS models and 2SLS models for both 2001 and 2009, the coefficient estimates for the telecommuter variable in the 2SLS models have increased compared to the OLS model estimates, since the 2SLS models are able to address the endogeneity bias. And the positive impact of telecommuting on work trip VMT in the 2SLS models further corroborate that telecommuters tend to choose to live farther away from their various work destinations, such as workplace, clients, and business partners.

\section{Worker's non-work trips}

In addition, we analyze the impact of telecommuting on worker's non-work trip VMT, as this is also an important part of their daily total trips. As suggested by our previous discussion and the Wald test of exogeneity, the telecommuter variable should be treated as exogenous in this case. Therefore, left-censored Tobit models are estimated to examine the impact of telecommuting on total non-work trip VMT, as well as on the VMT for each non-work trip category for all workers in the trip-diary sample. The same set of variables is used to control for the individual and household socioeconomic characteristics, household locational attributes, and transportation characteristics. Table 4 presents the Tobit regression results for worker's daily non-work trips (total daily nonwork trip VMT and VMT by each non-work trip type) in 2001 and 2009. Only the dependent variables,

\footnotetext{
${ }^{3}$ The first stage regression results are provided in Appendix 1.
} 
coefficient estimates and t-values for the telecommuter variable, numbers of observations and uncensored observations are reported in Table 4 in order to keep the table concise. Detailed regression results containing all control variables are provided in Appendices 3 and 4.

\section{[Table 4 about here]}

All coefficient estimates of the control variables are consistent with our expectations. Older workers typically have longer daily total non-work trip VMT as well as longer VMT in several non-work trip categories such as "shopping”, “family/personal business" and "medical/dental” trips. In both years, male workers have shorter VMT in almost all non-work trip categories. Highly educated workers have longer daily total non-work trip VMT as well as longer VMT in some of the non-work trip categories ("shopping” trips, family/personal business" trips, "visit friends/relatives" trips, and "other social/recreational” trips). Compared with suburban residents, living in an urbanized area involves significantly shorter non-work trip VMT. And as expected, "weekend” had a positive effect on VMT in all non-work trip categories for workers.

The variable of interest - telecommuter-had a positive impact on most of the non-work trip types in terms of VMT. This positive impact was (statistically) significant for all trip categories but "school/church" trips in 2001, and (statistically) significant for "shopping" trips, “other family/personal business" trips, and "other social/recreational” trips in 2009. When adding all of the types of non-work trips together, telecommuting had a significantly positive impact on worker’s daily total non-work trip VMT in both years.

\section{Daily total trips for workers and non-workers}

This research also analyzes the impact of telecommuting on individual's daily total trips, including worker's daily total (work and non-work) trips and non-worker's daily total (non-work) trips. More specifically, two separate questions are addressed: (1) how does telecommuting affect worker's daily total trip VMT; and (2) how do non-working adult's daily total trip VMT differ if his/her household has other members telecommuting.

\section{1) Worker's Daily Total Trips}

Table 5 presents the Instrumental Variable Tobit model estimates for the impact of telecommuting on worker's daily total trip VMT in 2001 and 2009. As the sum of daily work trip VMT and daily non-work trip VMT, worker's daily total trip VMT are also significantly longer if he/she is a telecommuter in both 2001 and 2009. Over this period, the impact of telecommuting on worker's daily total trip VMT has also substantially increased.

[Table 5 about here]

\section{2) Non-workers’ Daily Total Trips}

As indicated in Zhu (2013), telecommuting could also influence the travel behavior of the household nonworking members through its impact on the household residential location choice. Therefore, we also study how telecommuting could affect the non-work trip VMT for all non-workers in the trip-diary sample. The only change here is that the telecommuter dummy variable now indicates whether the non-working member is from a telecommuting household--namely, the household has other household members telecommuting. Different from telecommuters who could benefit directly from telecommuting and thus have 0 to/from work trip VMT on the telecommuting days, non-workers usually have many other reasons in determining their non-work travel demand. To avoid biased estimates of the impact of (working members') telecommuting on household nonworking members' daily non-work travel, we use the OLS models to only focus on those non-workers who have made non-work trips on the survey day. That is, we exclude those 0 VMT cases when studying the daily total non-work trip as well as each non-work trip category for non-workers. ${ }^{4}$ Table 6 presents the OLS model results for non-work trips made by the household non-working members in 2001 and 2009. Again, only the dependent variables, coefficient estimates and t-values for the telecommuting variable, number of observations and model r-squared values are reported in order to keep the table concise. Detailed regression results containing all control variables are provided in Appendices 5 and 6.

[Table 6 about here]

\footnotetext{
${ }^{4}$ We have also tested Tobit models which include those 0 non-work trip VMT cases for non-workers, the impact of telecommuting is still statistically insignificant.
} 
This is an author-produced, peer-reviewed version of this article. The final, definitive version of this document can be found online at International Journal of Environmental Science and Technology, published by Springer. Copyright restrictions may apply. doi: 10.1007/s13762-014-0556-5

All coefficient estimates of the control variables are similar to our previous results on the workers' non-work trips. However, the variable of interest--telecommuting household--shows no significant impact on the nonworker's daily total non-work trip VMT, since almost all coefficient estimates for the telecommuting dummy variable in all non-work trip categories in Table 6 are statistically insignificant. This result suggests that nonwork trip VMT of a household's non-working member are unaffected by the fact that other household members are telecommuting.

\section{Marginal effects of telecommuting on VMT}

Based on coefficient estimates in the Instrumental Variable Tobit models, Table 7 calculates the marginal effect of telecommuting on worker's daily work and non-work trip VMT, which takes into account the fact that some telecommuters and non-telecommuters do not have work or non-work travel on the survey day (i.e. the censoring). It shows that, in 2001, the median worker would have traveled, on any random day, 11.9 miles more for daily to/from work trip and 28.9 miles more for daily work related business trip, if he/she telecommutes; in 2009, the median worker would have traveled 33.7 miles more for to/from work trip VMT and 41.5 miles more for work related business trip VMT, has he/she telecommuted. On any random day, telecommuters on average travel 32.6 miles more by vehicles for their daily work trips than non-telecommuters in 2001, and 41.1 miles more in 2009. Note that these marginal effects are estimated after controlling for workers' demographic and household characteristics as well as location attributes.

[Table 7 about here]

Moreover, changing the status from non-telecommuting to telecommuting also incurs an increase of 5.4 miles in daily total non-work trip VMT in 2001 and an increase of 4.2 miles in 2009. Combining the effects on work trip VMT and non-work trip VMT, the marginal effect of telecommuting on daily total trip VMT indicates that, if the median worker telecommutes at some point, he/she would have had 38.0 miles more daily total trip VMT in 2001 and 45.3 miles more in 2009. ${ }^{5}$ The difference of this marginal effect between 2001 and 2009 also suggests the impact of telecommuting on worker's daily total trip VMT increases over time.

\section{$\mathrm{CO}_{2}$ emission calculations}

The translation of the outcome of VMT results in an overall increase in $\mathrm{CO}_{2}$ emissions. To arrive at these numbers we multiplied the combined the marginal effect of telecommuting on the worker's daily total trip VMT increase of 38 miles in 2001 and 45.3 miles in 2009 by 365 days to find the increase in miles each year due to telecommuting for the median telecommuter. We then used the employment data from the U.S. Census and multiplied that by the percentage of telecommuters for 2001 and 2009. As seen in Table 8, using the information in the previously noted EPA formula for calculating annual $\mathrm{CO}_{2}$ tailpipe emissions and the EPA's average passenger vehicle's MPG for 2001 of 19.6, telecommuting resulted in an additional 86,989,317 miles driven which generated 34,123,530 more metric tons of $\mathrm{CO}_{2}$. This is equivalent of putting 7,248,845 additional cars on the road in 2001. In 2009, using the EPA's average passenger vehicle's MPG for of 22.4, the increased miles of 105,697,985 resulted in 30,433,431 metric tons of additional $\mathrm{CO}_{2}$, or the equivalent of adding $8,808,165$ more cars to the road for that year. In the end, the effect of telecommuting on GHG emission shows an increase in $\mathrm{CO}_{2}$ emissions from telecommuting despite gains in fuel efficiency for motor vehicles. More over the number of miles driven appears to be increasing among telecommuters even though the percentage of telecommuters is not rising.

\section{[Table 8 about here]}

\section{Conclusion}

Even though there is and increasing awareness of the impacts of climate change, GHG emissions continue to be high. One possible explanation is the policies being put in place that could help reduce GHG reductions are not being monitored or measured systematically as a measure of total greenhouse production. It may be that specific policies with the potential to contribute to GHG reductions, when considered in isolation, fall victim to

\footnotetext{
${ }^{5}$ We also estimate the conditional marginal effects (conditional on being uncensored in the IV Tobit models and Tobit models). Our unconditional marginal effects, which take the censoring into account, are higher than the conditional marginal effects. This is because telecommuting not only increases the probability of having various work and non-work trips but also increases the VMT if that trip does happen.
} 
deviations from unexpected travel behavior changes due to the fact that new options stemming from telecommuting or improvements in fuel efficiency, for example, open up more opportunities to drive longer and create more GHG.

It appears that without holistic consideration of the options and potential outcomes for GHG reduction policies, anticipated decreases in some arenas will permit increases in other types of travel behavior in the form of substitution effects. Although using one-day trip diary in the national surveys may pose some concerns on the limitations of such data, the findings here on telecommuting as a measurable source of GHG emission reductions coincidences with other related literature. As previously noted rebound effects can cancel out or in this case further exacerbate the GHG emissions due to increased VMT. It appears that at times policies with the best intentions can result in unintended or negligible consequences for larger GHG emission goals. The fact that we find that as telecommuting persists, VMT increases over the two time periods and in turn increases $\mathrm{CO}_{2}$ emissions despite gains in fuel efficiency is noteworthy for policymakers. As Holden and Linnerud (2011) conclude the focus on a particular type of transport may miss the mark in terms of achieving true GHG reductions. This too may be the case with telecommuting for work. Although there are many benefits to telecommuting for both employers and employees the actual benefits and motivation to engage in telecommuting have to do with factors such as flexibility for the employee and reduced absenteeism for employers.

Underscoring the way GHG emission reductions should be considered as part of a larger system or dynamic is evidence by Fragkias et al. (2013) who found in U.S. urban areas $\mathrm{CO}_{2}$ emissions are proportional with urban areas population size. This is in contrast to belief that larger cities are more emission efficient than smaller ones due to economies of scale often identified with density or infrastructure such as transit systems. Similarly, Liao et al (2012) found GHG emissions from residence and transportation sectors correlated with urbanization. Moos et al. (2006) also contend that policy progress in sustainability can only be realized by extending our scope of understanding of impacts beyond single issues. The authors indicate it is necessary to consider the complex network or potential outcomes of any one policy such as telecommuting. Findings such as these suggest it may be time to re-think the way our methods could better meet our goals. If telecommuting holds any promise for reducing GHG emissions it must be understood and its benefits measured in terms of the way telecommuting contributes to other factors. The evidence provided here reveals a VMT increase suggesting a broader net may need to be cast to capture or understand the potential benefits of telecommuting for GHG reductions.

Taking a broad look at policy options may be becoming an important avenue for sustainability. In the transport sector Alam et. al. (2013) found the dominance of road transport policy left the city of Bangladesh with more uncertainties and less sustainable options than if they considered or prioritized transport options such as rail or water. Similarly to other scholars, we also conclude to achieve deep reductions needed in GHG emissions through transportation it will be necessary to look beyond the use of light duty trucks and cars and consider other transportation subsectors. Other sources of transportation emissions are anticipated to account for more than 50 percent of the transportation in emission in the U.S. by 2050 with aviation contributing a large part to that growth (McCollum and Yang, 2011, p 5594; IEA, 2008). As such, telecommuting has the potential to be a significant means to reduce GHG emission if not by reducing the use of light vehicle transportation options, but perhaps aviation and other subsectors. Our findings also lead us to concur with Holden and Linnerud (2011) that effective efforts at reducing GHG emissions could be benefited by being targeted to directly reduce $\mathrm{CO}_{2}$ emissions. It would be helpful to measure and study GHG reductions in a way that accounts for systematic deviations and options that pervade urban systems as Fragkias et al (2013) and Moos et al. (2006) suggest. The literature suggests the there is no silver bullet option such as mass transit, density, or telecommuting for reducing GHG emissions from the transportation sector. Individual behavior may be influenced to engage in activities that reduce GHG emissions on a number of fronts from walking to participating in internet-based multi-site conferences, but we may never know their true effects on GHG reduction if we only focus on VMT. Research suggests monitoring individual driving activity as the result of telecommuting credits is excessively burdensome making cap and trade policies for travel emissions an ineffective tool (Nelson, 2004). However, to ensure the individual choices beget GHG emissions reductions and not unintended consequences of more leisure travel for example, it may be worthwhile to explore ways to incentivize the reduction of GHG emissions directly to meet climate action planning goals. This could help to avoid the pitfalls of perverse deviations or leakages in outcomes that result from single issue policies or studies. Some scholars even argue going beyond measuring $\mathrm{CO}_{2}$ effects and including all pollutants and ecological footprint factors such as water use (Horvath, 2010). Steps such as measuring ecological footprints, integrating policy initiatives to capture the breadth of their effect (economic, physical and social), and looking at outcomes systematically or in conjunction with their effects on other transportations sectors, are all first steps for considering the effects of transportation choices such as telecommuting's potential impact on GHG emissions in a holistic and effective way. 
This is an author-produced, peer-reviewed version of this article. The final, definitive version of this document can be found online at International Journal of Environmental Science and Technology, published by Springer. Copyright restrictions may apply. doi: $10.1007 / \mathrm{s} 13762-014-0556-5$

\section{Acknowledgement}

We want to thank the editor and reviewers for their comments.

\section{References}

Alam, J. B. and Z. Wadud, J.W. Polak. (2013). Energy demand and economic consequences of transport policy. International Journal of Environmental Science Technology. 10: 1075-1082.

Balker, Ted. (2005). The Quiet Success: Telecommuting's Impact on Transportation and Beyond. Reason Foundation, California: Los Angeles. Retrieved June 9, $2013<$ http://reason.org/news/show/127673.html>

Buliung, Ron. N. (2007). Broadband Technology and Metropolitan Sustainability: An Interpretive Review. Report available from the Univeristy of Tornoto Focus on Research retrieved June 9, 2013 $<$ http://focus.library.utoronto.ca/works/11764>

Coroama, Vlad C., Lorenz M. Hilty, and Martin Birtel (2012). Effects of Internet-based multiple-site conferences on greenhouse gas emissions. Telematics and Informatics. 29(4): 362-374.

Cox, Wendell. (2009). Improving Quality of Life Through Telecommuting. The informational Technology and Innovation Foundation. Washington: D.C.

EPA (2013). Light-Duty Automotive Technology, Carbon Dioxide Emissions, and Fuel Economy Trends: 1975 Through 2012. Appendix A Database Details and Calculation Methods (March 2013). Retrieved February 12, 2014, from http://www.epa.gov/fueleconomy/fetrends/1975-2012/420r13001-appx-a.pdf

EPAa (2011). INVENTORY OF U.S. GREENHOUSE GAS EMISSIONS AND SINKS: 1990-2009 (April 2011). USEPA \#430-R-11-005 Retrieved November 23, 2011, from http://www.epa.gov/climatechange/emissions/downloads11/GHG-Fast-Facts-2009.pdf

EPAb (2011). Office of Transportation and Air Quality. EPA-420-F-11-04, December 2011. Questions and Answers: Greenhouse Gas Emissions from a Typical Passenger Vehicle. Retrieved June 8, 2013 from http://www.epa.gov/otaq/climate/ documents/ 20f11041.pdf.

Fuhr, Joseph P. and Stephen Pociask (2011). Boradband and Telecommuting: Helping the U.S. Environment and the Economy. Low Carbon Economy. 2: 41-47.

Fragkias M, Lobo J, Strumsky D, Seto KC (2013) Does Size Matter? Scaling of CO2 Emissions and U.S. Urban Areas. PLoS ONE 8(6): e64727. doi:10.1371/journal.pone.0064727

Holden, Erling and Kristin Linnerud. (2011). Troublesome Leisure Travel: The contradictions of three sustainable transport Policies. Urban Studies. 48(14) 3087-3106.

Horvath, Arpad. (2010). Environmental Analyses of Telework: What we Know, and What we Do Not Know and Why? Paper presented at the 2010 IEEE International Symposium on Sustainable Systems and Technology May 17-19, 2010, Arlington, VA.

IEA (2008). Energy and Technology Perspectives 2008: Scenarios and Strategies in 2050. International Energy Agency, Organization for Economic Co-operation and the Development (OECD), Paris France.

Khan, Ata (2010). Telecommuting as a Strategy for Reducing Energy Consumption and Greenhouse Gas Emissions in Multi-Nucleated Urban Regions. $12^{\text {th }}$ WCTR July 11-15, Lisbon, Portugal.

Kitou, Erasmia and Arpad Horvath. (2008). External Air Pollution Costs of Telework. International Journal of Life Cycle Management.13(2): 155-165.

Kitou, Erasmia and Arpad Horvath. (2003a). Energy Related Emission from Telework. Environmental Science and Technology. 37(16); 3467-3475.

Kitou, Erasmia and Arpad Horvath. (2003b). Transportation Choices and Air Pollution Effects of Telework. Journal of Infrastructures Systems.12 (2):121-134.

Lian C.-H., C.-L Chang, C.-Y Su, and P. -T Chiueh. (2013). Correlation between Land-Use Change and Greenhouse Gas Emissions in Urban Areas. International Journal of Environmental Science and Technology. 10: 1275-1286.

Lister, Kate and Tom Harnish. (2011). The State of Telework in the U.S.; How individuals, Business and Government Benefit. Telework Research Network. California: San Diego.

Matthews, H. Scott, and Eric Williams. (2005). Telework Adoption and Energy Use in Building and Transport Sectors in the United States and Japan. Journal of Infrastructure Systems. 11(1): 21-30.

McCollum, David and Christopher Yang (2009). Achieving deep reductions in US transport greenhouse gas emissions: Scenario analysis and policy implications. Energy Policy. 37:5580-5596.

Moos, Markus and Jean Andrey and Laura C. Johnson. (2006). The sustainability of telework: an ecologicalfootprinting approach. Sustainability: Science, Practice \& Policy. 2(1): 3-14.

Nelson, Peter. (2004). Emissions Trading with Telecommuting Credits: Regulatory Background an Institutional Barriers. Resources for the Future: Washington: D.C. 
This is an author-produced, peer-reviewed version of this article. The final, definitive version of this document can be found online at International Journal of Environmental Science and Technology, published by Springer. Copyright restrictions may apply. doi: 10.1007/s13762-014-0556-5

New York Times, (2011). Carmakers Back Strict New Rules for Gas Mileage. By BILL VLASIC Published: July 28, 2011 Retrieved November 232011 from $<$ http://www.nytimes.com/2011/07/29/business/carmakers-back-strict-new-rules-forgasmileage.html?page wanted=all $>$.

Roth, Kurt W., Todd Rhodes, and Rarcharit Ponnum. (2008). The Energy and Greenhouse Gas Emission Impacts of Telecommuting in the U.S. Proceedings from the 2008 IEEE International Symposium on Electronics and the Environment, 1-6.

Shafizadeh, Kevan R, Debbie A Niemeier, Patrica L Mokhtarian and Ilan Salomon. (2007). Cost and Benefits of Home-Based Telecommuting: A Monte Carlo Simulation Model Incorporating Telecommuter, Employer, and Public Sector Perspectives. Journal of Infrastructure Systems. 13(1): 12-25.

Tang, Wei (Laura), Patricia L. Mokhtarian and Susan Handy (2011). The impact of the residential built environment on work at home adoption and frequency: An example from Northern California. The Journal of Transportation and Land Use. 4(3): 3-22.

Tayyaran, Mohammad R. and Ata M. Khan. (2003). The Effects of Telecommuting and Intelligent Transportation Systems on Urban Development. Journal of Urban Technology. 10(2): 87-100.

Urban Land Institute. 2009. Moving Cooler: An Analysis of Transportation strategies for reducing greenhouse gas emissions. Urban Land Institute: Washington D.C.

U.S. Bureau of Labor Statistics (2012) Labor Force Statistics from the Current Population Survey Data, 2009 Annual Average-House Data-Tables form Employment and Earnings. "Employment Status of the Civilian noninstitutional Population, 1940s to date.” Retrieved July 24, 2012 from http://www.bls.gov/cps/cps_aa2009.htm

Winkelman, Steve, Allison Bishins and Chuck Kooshian (2009). Cost-Effective GHG Reductions through Smart Growth \& Improved Transportation Choices: An economic case for investment of cap-and-trade revenues. Center for Clear Air Policy: Washington D.C.

Yang, Christopher, David McCollum, Ryan McCarthy, and Wayne Leighty (2009). Meeting an 80\% reduction in greenhouse gas emission from transportation by 2030: A case study in California. Transportation Research Part D. 14: 147-156.

Zhu, Pengyu (2011). Telecommuting, travel behavior and residential location choice: Can telecommuting be an effective policy to reduce travel demand? Ph.D. Dissertation, University of Southern California

Zhu, Pengyu (2012). Are Telecommuting and Personal Travel Complements or Substitutes? The Annals of Regional Science. 48(2), 619-639.

Zhu, Pengyu (2013). Telecommuting, Household Commute and Location Choice. Urban Studies. doi: 10.1177/0042098012474520 
Table 1 Comparison of daily work trip and non-work trip VMT by worker's telecommuting status 2001 and 2009

\begin{tabular}{|c|c|c|c|c|c|c|c|c|}
\hline \multirow{3}{*}{ Variable } & \multicolumn{4}{|c|}{2001} & \multicolumn{4}{|c|}{2009} \\
\hline & \multicolumn{2}{|c|}{ non-telecommuters } & \multicolumn{2}{|c|}{ telecommuters } & \multicolumn{2}{|c|}{ non-telecommuters } & \multicolumn{2}{|c|}{ telecommuters } \\
\hline & Mean & Obs & Mean & Obs & Mean & Obs & Mean & Obs \\
\hline \multicolumn{9}{|c|}{$\begin{array}{c}\text { Excluding workers with } 0 \text { VMT in each } \\
\text { category }\end{array}$} \\
\hline Total work trip VMT & 27.2 & 40221 & 37.3 & 1569 & 28.2 & 66140 & 39.5 & 2345 \\
\hline total to/from work trip VMT & 23.4 & 38899 & 26.8 & 1335 & 24.8 & 62753 & 34.4 & 1875 \\
\hline $\begin{array}{l}\text { total work related business trip } \\
\text { VMT }\end{array}$ & 39.5 & 4598 & 44.8 & 510 & 36.8 & 8358 & 38.8 & 726 \\
\hline Total non-work trip VMT & 33.9 & 46820 & 40.5 & 2468 & 31.5 & 77775 & 36.4 & 4085 \\
\hline total shopping trip VMT & 16.4 & 24681 & 18.6 & 1410 & 15.5 & 39972 & 16.7 & 2111 \\
\hline $\begin{array}{l}\text { total other family/personal } \\
\text { business trip VMT }\end{array}$ & 16.6 & 22979 & 21.3 & 1287 & 16.5 & 36344 & 19.7 & 2066 \\
\hline total school/church trip VMT & 14.7 & 5806 & 15.7 & 251 & 16.0 & 9093 & 18.4 & 368 \\
\hline total medical/dentral trip VMT & 16.8 & 2647 & 21.1 & 172 & 18.8 & 5129 & 18.3 & 282 \\
\hline total visit friends/relatives trip VMT & 31.5 & 8288 & 36.7 & 401 & 29.9 & 11431 & 34.8 & 525 \\
\hline $\begin{array}{l}\text { total other social/recreational trip } \\
\text { VMT } \\
\end{array}$ & 22.1 & 18560 & 21.8 & 1101 & 20.0 & 32402 & 21.4 & 1984 \\
\hline Total trip VMT & 44.3 & 60415 & 55.3 & 2865 & 42.3 & 101999 & 51.2 & 4713 \\
\hline \multicolumn{9}{|c|}{$\begin{array}{c}\text { Including workers with } 0 \text { VMT in each } \\
\text { category }\end{array}$} \\
\hline Total work trip VMT & 16.1 & 67911 & 18.0 & 3264 & 16.2 & 115047 & 16.8 & 5514 \\
\hline total to/from work trip VMT & 13.4 & 67911 & 11.0 & 3264 & 13.5 & 115047 & 11.7 & 5514 \\
\hline $\begin{array}{l}\text { total work related business trip } \\
\text { VMT }\end{array}$ & 2.7 & 67911 & 7.0 & 3264 & 2.7 & 115047 & 5.1 & 5514 \\
\hline Total non-work trip VMT & 23.3 & 67911 & 30.6 & 3264 & 21.3 & 115047 & 27.0 & 5514 \\
\hline total shopping trip VMT & 5.9 & 67911 & 8.1 & 3264 & 5.4 & 115047 & 6.4 & 5514 \\
\hline $\begin{array}{l}\text { total other family/personal } \\
\text { business trip VMT }\end{array}$ & 5.6 & 67911 & 8.4 & 3264 & 5.2 & 115047 & 7.4 & 5514 \\
\hline total school/church trip VMT & 1.3 & 67911 & 1.2 & 3264 & 1.3 & 115047 & 1.2 & 5514 \\
\hline total medical/dentral trip VMT & 0.7 & 67911 & 1.1 & 3264 & 0.8 & 115047 & 0.9 & 5514 \\
\hline total visit friends/relatives trip VMT & 3.8 & 67911 & 4.5 & 3264 & 3.0 & 115047 & 3.3 & 5514 \\
\hline $\begin{array}{l}\text { total other social/recreational trip } \\
\text { VMT }\end{array}$ & 6.0 & 67911 & 7.4 & 3264 & 5.6 & 115047 & 7.7 & 5514 \\
\hline Total trip VMT & 39.4 & 67911 & 48.6 & 3264 & 37.5 & 115047 & 43.8 & 5514 \\
\hline
\end{tabular}

Notes: 1. Based on two-sample t test with unequal variances, those types of trips marked in bold fonts means the VMTby non-telecommuters are statistically different from the VMT by telecommuters, at 95\% confidence level. 
This is an author-produced, peer-reviewed version of this article. The final, definitive version of this document can be found online at International Journal of Environmental Science and Technology, published by Springer. Copyright restrictions may apply. doi: $10.1007 /$ s13762-014-0556-5

Table 2 Summary Statistics

\begin{tabular}{|c|c|c|c|c|}
\hline \multirow[b]{2}{*}{ Variable } & \multicolumn{2}{|c|}{2001} & \multicolumn{2}{|c|}{2009} \\
\hline & Mean & Std. Dev. & Mean & Std. Dev. \\
\hline Total trip VMT & 39.86 & 54.78 & 37.77 & 50.97 \\
\hline Total work trip VMT & 16.19 & 32.57 & 16.22 & 30.66 \\
\hline Total non-work trip VMT & 23.68 & 46.73 & 21.55 & 43.58 \\
\hline Telecommuter (dummy) & 0.05 & 0.21 & 0.05 & 0.21 \\
\hline Age & 41.83 & 12.99 & 47.56 & 13.54 \\
\hline Male & 0.51 & 0.50 & 0.51 & 0.50 \\
\hline Medical Condition & 0.02 & 0.15 & 0.03 & 0.17 \\
\hline Less than highschool & 0.07 & 0.26 & 0.04 & 0.19 \\
\hline High Sch. Grad. Some College & 0.51 & 0.50 & 0.53 & 0.50 \\
\hline BA Degree & 0.29 & 0.46 & 0.24 & 0.43 \\
\hline Graduate Degree & 0.13 & 0.33 & 0.19 & 0.39 \\
\hline Sales or Service & 0.26 & 0.44 & 0.26 & 0.44 \\
\hline Clerical or Administrative Support & 0.13 & 0.34 & 0.13 & 0.33 \\
\hline Manufacturing, Construction, Maintenance, or & & & & \\
\hline Farming & 0.18 & 0.39 & 0.14 & 0.35 \\
\hline Professional, Managerial or Technical & 0.42 & 0.49 & 0.46 & 0.50 \\
\hline Other Occupation & 0.00 & 0.07 & 0.01 & 0.09 \\
\hline Household Income & 61549.27 & 32511.73 & 75170.45 & 35792.99 \\
\hline Child & 0.40 & 0.49 & 0.34 & 0.47 \\
\hline Num. of Vehicles in Household per Driver & 1.12 & 0.49 & 1.17 & 0.49 \\
\hline Residence in Urbanized Area & 0.62 & 0.48 & 0.61 & 0.49 \\
\hline Residence in Suburban Area & 0.20 & 0.40 & 0.21 & 0.41 \\
\hline Residence in Rural Area & 0.17 & 0.38 & 0.17 & 0.38 \\
\hline Not in an MSA or CMSA & 0.18 & 0.39 & 0.19 & 0.39 \\
\hline In an MSA Less than 250,000 & 0.18 & 0.39 & 0.12 & 0.32 \\
\hline In an MSA of 250,000 - 499,999 & 0.18 & 0.38 & 0.08 & 0.27 \\
\hline In an MSA of 500,000 - 999,999 & 0.09 & 0.29 & 0.11 & 0.31 \\
\hline In an MSA or CMSA of 1- 3 millions & 0.12 & 0.33 & 0.22 & 0.41 \\
\hline In an MSA or CMSA of 3 million or more & 0.24 & 0.43 & 0.29 & 0.45 \\
\hline Trip day is weekend & 0.27 & 0.44 & 0.29 & 0.45 \\
\hline
\end{tabular}

Notes: 1 . Telecommuter is a dummy variable indicating whether the worker is telecommuting frequently (see definitions in the paper).

2. Medical Condition is a dummy variable indicating whether this person has a temporary or permanent condition or handicap that makes it difficult to travel outside of the home.

3. For education dummy variables, "less than high school" will be used as the reference in regressions;

4. For occupation dummy variables, "Manufacturing, Cons., Maintenance, or Farming" will be reference;

5. For place of residence dummy variables, "residence in suburban area" will be the reference;

6. For MSA size dummy variables, "in an MSA of less than 250,000" will be the reference;

7. Workers with 0 trip VMT are included in the summary statistics. 
Table 3 Instrumental Variable (IV) Tobit model results for workers' daily work trip VMT, 2001 and 2009

\begin{tabular}{|c|c|c|c|c|c|c|}
\hline & \multicolumn{3}{|c|}{2001} & \multicolumn{3}{|c|}{2009} \\
\hline Variables & $\begin{array}{l}\text { 1) IV tobit } \\
\text { total work } \\
\text { trip VMT }\end{array}$ & $\begin{array}{l}\text { 2) IV tobit } \\
\text { to/from } \\
\text { work trip } \\
\text { VMT }\end{array}$ & $\begin{array}{c}\text { 3) IV tobit } \\
\text { work related } \\
\text { business trip } \\
\text { VMT }\end{array}$ & $\begin{array}{l}\text { 4) IV tobit } \\
\text { total work } \\
\text { trip VMT }\end{array}$ & $\begin{array}{l}\text { 5) IV tobit } \\
\text { to/from } \\
\text { work trip } \\
\text { VMT }\end{array}$ & $\begin{array}{c}\text { 6) IV tobit } \\
\text { work related } \\
\text { business trip } \\
\text { VMT }\end{array}$ \\
\hline Telecommuter (dummy) & $\begin{array}{c}69.509 * * * \\
(5.78)\end{array}$ & $\begin{array}{c}24.113^{* * *} \\
(2.87)\end{array}$ & $\begin{array}{c}374.567 * * * \\
(7.11)\end{array}$ & $\begin{array}{c}88.964^{* * *} \\
(4.00)\end{array}$ & $\begin{array}{c}73.472 * * * \\
(4.14)\end{array}$ & $\begin{array}{c}428.608 * * * \\
(4.67)\end{array}$ \\
\hline Age & $\begin{array}{c}-0.059 * * * \\
(-2.91)\end{array}$ & $\begin{array}{c}-0.086 * * * \\
(-6.05)\end{array}$ & $\begin{array}{c}0.328 * * * \\
(3.56)\end{array}$ & $\begin{array}{c}-0.086^{* * *} \\
(-4.31)\end{array}$ & $\begin{array}{c}-0.129 * * * \\
(-8.12)\end{array}$ & $\begin{array}{c}0.259 * * * \\
(3.13)\end{array}$ \\
\hline Male & $\begin{array}{c}10.524 * * * \\
(23.35)\end{array}$ & $\begin{array}{c}6.240^{* * *} \\
(19.58)\end{array}$ & $\begin{array}{c}33.847 * * * \\
(16.46)\end{array}$ & $\begin{array}{c}9.273 * * * \\
(23.52)\end{array}$ & $\begin{array}{c}5.435^{* * *} \\
(17.29)\end{array}$ & $\begin{array}{c}22.506 * * * \\
(14.03)\end{array}$ \\
\hline Medical Condition & $\begin{array}{c}-13.689 * * * \\
(-9.24)\end{array}$ & $\begin{array}{c}-10.373 * * * \\
(-9.84)\end{array}$ & $\begin{array}{c}-26.255^{* * *} \\
(-3.75)\end{array}$ & $\begin{array}{c}-14.683^{* * *} \\
(-13.09)\end{array}$ & $\begin{array}{c}-11.755^{* * *} \\
(-13.14)\end{array}$ & $\begin{array}{c}-29.819 * * * \\
(-6.19)\end{array}$ \\
\hline High Sch. Grad. Some Col. & $\begin{array}{c}7.128 * * * \\
(8.15)\end{array}$ & $\begin{array}{c}6.537 * * * \\
(10.56)\end{array}$ & $\begin{array}{c}10.422^{* *} \\
(2.44)\end{array}$ & $\begin{array}{c}4.050 * * * \\
(4.67)\end{array}$ & $\begin{array}{c}2.560 * * * \\
(3.71)\end{array}$ & $\begin{array}{c}12.845^{* * *} \\
(3.43)\end{array}$ \\
\hline BA Degree & $\begin{array}{c}5.790 * * * \\
(5.61)\end{array}$ & $\begin{array}{c}5.868 * * * \\
(8.05)\end{array}$ & $\begin{array}{c}12.508^{* *} \\
(2.55)\end{array}$ & $\begin{array}{l}0.986 \\
(0.88)\end{array}$ & $\begin{array}{l}-0.261 \\
(-0.29)\end{array}$ & $\begin{array}{c}10.227 * * \\
(2.17)\end{array}$ \\
\hline Graduate Degree & $\begin{array}{l}-0.613 \\
(-0.45)\end{array}$ & $\begin{array}{l}1.509 \\
(1.57)\end{array}$ & $\begin{array}{l}6.015 \\
(0.97)\end{array}$ & $\begin{array}{c}-3.884 * * * \\
(-2.90)\end{array}$ & $\begin{array}{c}-4.577 * * * \\
(-4.29)\end{array}$ & $\begin{array}{l}7.678 \\
(1.37)\end{array}$ \\
\hline Sales or Service & $\begin{array}{l}0.935 \\
(1.15)\end{array}$ & $\begin{array}{l}-0.606 \\
(-1.06)\end{array}$ & $\begin{array}{c}17.781^{* * *} \\
(4.42)\end{array}$ & $\begin{array}{l}-0.735 \\
(-0.99)\end{array}$ & $\begin{array}{c}-3.704 * * * \\
(-6.25)\end{array}$ & $\begin{array}{c}20.070^{* * *} \\
\quad(6.15)\end{array}$ \\
\hline Manuf, const, maint, farming & $\begin{array}{c}4.651 * * * \\
(5.66)\end{array}$ & $\begin{array}{c}2.789 * * * \\
(4.81)\end{array}$ & $\begin{array}{c}21.498^{* * *} \\
(5.32)\end{array}$ & $\begin{array}{c}2.393^{* * *} \\
(3.56)\end{array}$ & $\begin{array}{l}-0.091 \\
(-0.17)\end{array}$ & $\begin{array}{c}27.117^{* * *} \\
(9.31)\end{array}$ \\
\hline Professional/managerial & $\begin{array}{c}2.352 * * * \\
(3.24)\end{array}$ & $\begin{array}{c}1.567 * * * \\
(3.06)\end{array}$ & $\begin{array}{c}18.874 * * * \\
(5.15)\end{array}$ & $\begin{array}{l}-0.275 \\
(-0.41)\end{array}$ & $\begin{array}{c}-1.279 * * \\
(-2.43)\end{array}$ & $\begin{array}{c}10.846 * * * \\
(3.70)\end{array}$ \\
\hline Other Occupations & $\begin{array}{l}3.930 \\
(1.23)\end{array}$ & $\begin{array}{l}4.232 * \\
(1.89)\end{array}$ & $\begin{array}{l}6.192 \\
(0.40)\end{array}$ & $\begin{array}{c}-6.534 * * * \\
(-3.30)\end{array}$ & $\begin{array}{c}-7.961 * * * \\
(-5.04)\end{array}$ & $\begin{array}{c}20.793 * * * \\
(2.63)\end{array}$ \\
\hline Household Income (log) & $\begin{array}{c}3.911^{* * *} \\
(10.67)\end{array}$ & $\begin{array}{c}3.014^{* * *} \\
(11.63)\end{array}$ & $\begin{array}{c}5.846 * * * \\
(3.44)\end{array}$ & $\begin{array}{c}2.891 * * * \\
(6.60)\end{array}$ & $\begin{array}{c}1.816^{* * *} \\
(5.21)\end{array}$ & $\begin{array}{c}3.757 * * \\
(2.07)\end{array}$ \\
\hline Child & $\begin{array}{l}0.232 \\
(0.52)\end{array}$ & $\begin{array}{l}0.045 \\
(0.14)\end{array}$ & $\begin{array}{l}1.215 \\
(0.61)\end{array}$ & $\begin{array}{l}-0.600 \\
(-1.34)\end{array}$ & $\begin{array}{c}-0.809 * * \\
(-2.27)\end{array}$ & $\begin{array}{l}-2.200 \\
(-1.21)\end{array}$ \\
\hline Num. of Vehicles per Driver & $\begin{array}{c}6.769 * * * \\
(15.56)\end{array}$ & $\begin{array}{c}4.914^{* * * *} \\
(15.98)\end{array}$ & $\begin{array}{c}12.168 * * * \\
(6.75)\end{array}$ & $\begin{array}{c}4.457 * * * \\
(13.33)\end{array}$ & $\begin{array}{c}3.146 * * * \\
(11.79)\end{array}$ & $\begin{array}{c}7.785^{* * * *} \\
(6.17)\end{array}$ \\
\hline Residence in Urbanized Area & $\begin{array}{c}-7.132 * * * \\
(-13.22)\end{array}$ & $\begin{array}{c}-6.637 * * * \\
(-17.42)\end{array}$ & $\begin{array}{l}-4.171 * \\
(-1.75)\end{array}$ & $\begin{array}{c}-7.032 * * * \\
(-16.97)\end{array}$ & $\begin{array}{c}-6.253 * * * \\
(-18.94)\end{array}$ & $\begin{array}{c}-3.047 * \\
(-1.82)\end{array}$ \\
\hline Residence in Rural Area & $\begin{array}{c}5.130 * * \\
(2.04)\end{array}$ & $\begin{array}{l}1.456 \\
(0.82)\end{array}$ & $\begin{array}{c}30.728 * * * \\
(2.73)\end{array}$ & $\begin{array}{l}2.421^{*} \\
(1.77)\end{array}$ & $\begin{array}{l}1.581 \\
(1.45)\end{array}$ & $\begin{array}{l}6.844 \\
(1.29)\end{array}$ \\
\hline Not in a MSA & $\begin{array}{c}-4.105 * \\
(-1.66)\end{array}$ & $\begin{array}{l}-1.028 \\
(-0.59)\end{array}$ & $\begin{array}{c}-31.974 * * * \\
(-2.90)\end{array}$ & $\begin{array}{l}-2.429 * \\
(-1.79)\end{array}$ & $\begin{array}{l}-1.613 \\
(-1.49)\end{array}$ & $\begin{array}{l}-6.214 \\
(-1.17)\end{array}$ \\
\hline In a MSA of $250,000-499,999$ & $\begin{array}{l}1.052 \\
(1.53)\end{array}$ & $\begin{array}{c}1.214^{* *} \\
(2.50)\end{array}$ & $\begin{array}{c}-5.309 * \\
(-1.75)\end{array}$ & $\begin{array}{c}1.696 * * \\
(2.37)\end{array}$ & $\begin{array}{c}1.697 * * * \\
(2.96)\end{array}$ & $\begin{array}{l}-1.024 \\
(-0.36)\end{array}$ \\
\hline In a MSA of $500,000-999,999$ & $\begin{array}{c}1.919 * * \\
(2.31)\end{array}$ & $\begin{array}{c}2.575^{* * * *} \\
(4.37)\end{array}$ & $\begin{array}{c}-10.164^{* * *} \\
(-2.72)\end{array}$ & $\begin{array}{c}1.822^{* * *} \\
(2.67)\end{array}$ & $\begin{array}{c}2.289 * * * \\
(4.19)\end{array}$ & $\begin{array}{l}-4.233 \\
(-1.56)\end{array}$ \\
\hline In a MSA or CMSA of $1-3 \mathrm{~m}$ & $3.414^{* * *}$ & $3.601 * * *$ & $-7.242 * *$ & 0.668 & $2.084 * * *$ & $-13.113^{* * *}$ \\
\hline
\end{tabular}


This is an author-produced, peer-reviewed version of this article. The final, definitive version of this document can be found online at International

Journal of Environmental Science and Technology, published by Springer. Copyright restrictions may apply. doi: 10.1007/s13762-014-0556-5

\begin{tabular}{|c|c|c|c|c|c|c|}
\hline & $(4.48)$ & (6.69) & $(-2.15)$ & $(1.06)$ & $(4.14)$ & $(-5.17)$ \\
\hline In a MSA or CMSA over 3m & $\begin{array}{c}1.531^{* *} \\
(2.29)\end{array}$ & $\begin{array}{c}3.585^{* * *} \\
(7.58)\end{array}$ & $\begin{array}{c}-18.781^{* * *} \\
(-6.27)\end{array}$ & $\begin{array}{l}-0.258 \\
(-0.35)\end{array}$ & $\begin{array}{c}1.807 * * * \\
(3.07)\end{array}$ & $\begin{array}{c}-23.161^{* * *} \\
(-7.70)\end{array}$ \\
\hline Trip day is weekend & $\begin{array}{c}-49.294 * * * \\
(-89.88)\end{array}$ & $\begin{array}{c}-38.041^{* * *} \\
(-96.06)\end{array}$ & $\begin{array}{c}-60.560 * * * \\
(-23.49)\end{array}$ & $\begin{array}{c}-52.449 * * * \\
(-124.09)\end{array}$ & $\begin{array}{c}-43.513^{* * *} \\
(-126.81)\end{array}$ & $\begin{array}{c}-49.323^{* * *} \\
(-29.11)\end{array}$ \\
\hline Intercept & $\begin{array}{c}-48.229 * * * \\
(-11.51)\end{array}$ & $\begin{array}{c}-32.381 * * * \\
(-10.94)\end{array}$ & $\begin{array}{c}-303.421 * * * \\
(-15.38)\end{array}$ & $\begin{array}{c}-26.043 * * * \\
(-4.77)\end{array}$ & $\begin{array}{c}-8.994 * * \\
(-2.07)\end{array}$ & $\begin{array}{c}-248.481^{* * *} \\
(-10.91)\end{array}$ \\
\hline Observations & 62874 & 62874 & 62874 & 107580 & 107580 & 107580 \\
\hline Uncensored observations & 36946 & 35584 & 4554 & 61478 & 57991 & 8293 \\
\hline Model goodness of fit & 0.052 & 0.081 & - & 0.051 & 0.056 & - \\
\hline
\end{tabular}

z-statistics in parentheses; ${ }^{* * *} \mathrm{p}<0.01,{ }^{* *} \mathrm{p}<0.05,{ }^{*} \mathrm{p}<0.1$

1. For education dummy variables, the reference is "less than high school".

2. For occupation dummy variables, the reference is "Clerical and administrative support".

3. For place of residence dummy variables, the reference is "residence in suburban area".

4. For MSA size dummy variables, the reference is "in an MSA of less than 250,000".

5. Sample is restricted to workers who used personal vehicles for various trips.

6. The model goodness of fit is calculated as the square of the correlation between observed and predicted responses. 
This is an author-produced, peer-reviewed version of this article. The final, definitive version of this document can be found online at International Journal of Environmental Science and Technology, published by Springer. Copyright restrictions may apply. doi: 10.1007/s13762-014-0556-5

Table 4 Tobit Model Results for Worker's Daily Non-work Trip VMT

\begin{tabular}{|c|c|c|c|c|c|c|c|c|}
\hline \multirow[b]{2}{*}{ Trip Type } & \multicolumn{4}{|c|}{ (1) Tobit model 2001} & \multicolumn{4}{|c|}{ (2) Tobit model 2009} \\
\hline & $\begin{array}{c}\text { Telecom } \\
\text { muter } \\
\text { (dummy) }\end{array}$ & t-value & $\begin{array}{l}\text { number } \\
\text { of obs }\end{array}$ & $\begin{array}{l}\text { Uncensored } \\
\text { observations }\end{array}$ & $\begin{array}{c}\text { Telecommuter } \\
\text { (dummy) }\end{array}$ & t-value & $\begin{array}{l}\text { number } \\
\text { of obs }\end{array}$ & $\begin{array}{c}\text { uncensored } \\
\text { observations }\end{array}$ \\
\hline Total Nonwork Trips & $9.498^{* * *}$ & $(8.29)$ & 66,333 & 46342 & $7.628 * * *$ & $(8.84)$ & 107580 & 73316 \\
\hline $\begin{array}{c}\text { Shopping Trips } \\
\text { Other Family/Personal }\end{array}$ & $5.821^{* * *}$ & $(6.92)$ & 66,333 & 24542 & $3.103^{* * *}$ & $(4.78)$ & 107580 & 38094 \\
\hline Business Trips & $5.528 * * *$ & $(6.15)$ & 66,333 & 22942 & $4.885^{* * *}$ & $(6.82)$ & 107580 & 34760 \\
\hline School/Church Trips & -0.287 & $(-0.22)$ & 66,333 & 5675 & -0.240 & $(-0.20)$ & 107580 & 7876 \\
\hline $\begin{array}{l}\text { Medical/Dentral Trips } \\
\text { Visit Friend/Relatives }\end{array}$ & $5.939 * * *$ & $(2.98)$ & 66,333 & 2643 & 2.713 & $(1.62)$ & 107580 & 4868 \\
\hline $\begin{array}{c}\text { Trips } \\
\text { Oth Social/Recreation }\end{array}$ & $6.542 * * *$ & $(2.61)$ & 66,333 & 8175 & 2.943 & (1.38) & 107580 & 10735 \\
\hline Trips & $5.028 * * *$ & $(4.04)$ & 66,333 & 18535 & $5.895 * * *$ & $(6.83)$ & 107580 & 30719 \\
\hline
\end{tabular}

t-statistics in parentheses

$* * * \mathrm{p}<0.01, * * \mathrm{p}<0.05, * \mathrm{p}<0.1$

1. For all models, control variables include age, male, medical condition, education, occupation, household income (log), child, number of vehicles per driver, residence in urbanized area, residence in rural area, not in a MSA,in a MSA of 250000-499999, in a MSA of 500000-999999, in a MSA or CMSA of 1-2 millions, In a MSA or CMSA over 3 million or more, weekend.

2. Coefficient estimates for all control variables are not shown.

3. The telecommuting dummy variable used is whether the worker is a telecommuter.

4. The sample is restricted to workers who used personal vehicles in these non-work trips. 
Table 5 Instrumental Variable Tobit Model Results for Worker's Daily Total Trip VMT

\begin{tabular}{|c|c|c|}
\hline & 2001 & 2009 \\
\hline Variables & $\begin{array}{l}\text { 1) IV Tobit daily total } \\
\text { trip VMT }\end{array}$ & $\begin{array}{l}\text { 2) IV Tobit daily total trip } \\
\text { VMT }\end{array}$ \\
\hline \multirow[t]{2}{*}{ Telecommuter (dummy) } & $150.768 * * *$ & $261.940 * * *$ \\
\hline & $(9.87)$ & (7.91) \\
\hline \multirow[t]{2}{*}{ Age } & $-0.139 * * *$ & $-0.128 * * *$ \\
\hline & $(-5.33)$ & $(-4.32)$ \\
\hline \multirow[t]{2}{*}{ Male } & $5.693 * * *$ & $3.713^{* * *}$ \\
\hline & (9.71) & (6.34) \\
\hline \multirow[t]{2}{*}{ Medical Condition } & $-10.960 * * *$ & $-16.893 * * *$ \\
\hline & $(-5.93)$ & $(-10.52)$ \\
\hline \multirow[t]{2}{*}{ High Sch. Grad. Some Col. } & $6.243 * * *$ & $5.733 * * *$ \\
\hline & (5.55) & $(4.47)$ \\
\hline \multirow[t]{2}{*}{ BA Degree } & $6.393 * * *$ & -0.065 \\
\hline & $(4.81)$ & $(-0.04)$ \\
\hline \multirow[t]{2}{*}{ Graduate Degree } & -1.653 & $-5.949 * * *$ \\
\hline & $(-0.95)$ & $(-3.00)$ \\
\hline \multirow[t]{2}{*}{ Sales or Service } & $-3.337 * * *$ & $-5.619 * * *$ \\
\hline & $(-3.19)$ & $(-5.09)$ \\
\hline \multirow[t]{2}{*}{ Manuf, const, maint, farming } & $1.935^{*}$ & 0.735 \\
\hline & $(1.82)$ & $(0.74)$ \\
\hline \multirow[t]{2}{*}{ Professional/managerial } & 0.065 & $-3.407 * * *$ \\
\hline & $(0.07)$ & $(-3.47)$ \\
\hline \multirow[t]{2}{*}{ Other Occupations } & -3.043 & $-7.153^{* *}$ \\
\hline & $(-0.72)$ & $(-2.48)$ \\
\hline \multirow[t]{2}{*}{ Household Income (log) } & $6.204 * * *$ & $3.264 * * *$ \\
\hline & (13.19) & $(5.03)$ \\
\hline \multirow[t]{2}{*}{ Child } & $1.279 * *$ & $1.539 * *$ \\
\hline & $(2.20)$ & $(2.32)$ \\
\hline \multirow[t]{2}{*}{ Num. of Vehicles per Driver } & $9.754^{* * *}$ & $6.724^{* * *}$ \\
\hline & (17.06) & (13.42) \\
\hline \multirow[t]{2}{*}{ Residence in Urbanized Area } & $-9.846 * * *$ & $-9.169 * * *$ \\
\hline & $(-13.94)$ & $(-14.84)$ \\
\hline \multirow[t]{2}{*}{ Residence in Rural Area } & $6.729 * *$ & $6.459 * * *$ \\
\hline & $(2.08)$ & $(3.20)$ \\
\hline \multirow[t]{2}{*}{ Not in a MSA } & $-7.276^{* *}$ & $-4.460 * *$ \\
\hline & $(-2.30)$ & $(-2.23)$ \\
\hline \multirow[t]{2}{*}{ In a MSA of $250,000-499,999$} & $-1.474 *$ & 1.134 \\
\hline & $(-1.66)$ & $(1.06)$ \\
\hline \multirow[t]{2}{*}{ In a MSA of $500,000-999,999$} & $-3.463 * * *$ & $2.288^{* *}$ \\
\hline & $(-3.20)$ & $(2.25)$ \\
\hline \multirow[t]{2}{*}{ In a MSA or CMSA of $1-3 m$} & 0.436 & -1.148 \\
\hline & $(0.44)$ & $(-1.23)$ \\
\hline \multirow[t]{2}{*}{ In a MSA or CMSA over 3m } & $-5.706 * * *$ & $-5.323 * * *$ \\
\hline & $(-6.56)$ & $(-4.86)$ \\
\hline
\end{tabular}


This is an author-produced, peer-reviewed version of this article. The final, definitive version of this document can be found online at International Journal of Environmental Science and Technology, published by Springer. Copyright restrictions may apply. doi: 10.1007/s13762-014-0556-5

Trip day is weekend

Intercept
$-1.014 *$

$(-1.67)$

$-42.313^{* * *}$

$(-7.88)$
$-4.909 * * *$

Observations

62874

107580

Uncensored observations

56108

95467

z-statistics in parentheses; $* * * \mathrm{p}<0.01, * * \mathrm{p}<0.05$, * $\mathrm{p}<0.1$

1. For education dummy variables, the reference is "less than high school";

2. For occupation dummy variables, the reference is "Clerical and administrative support";

3. For place of residence dummy variables, the reference is "residence in suburban area";

4. For MSA size dummy variables, the reference is "in an MSA of less than 250,000";

5. Sample is restricted to workers who used personal vehicles for various trips. 
This is an author-produced, peer-reviewed version of this article. The final, definitive version of this document can be found online at International Journal of Environmental Science and Technology, published by Springer. Copyright restrictions may apply. doi: 10.1007/s13762-014-0556-5

Table 6 OLS Model Results for Non-worker's Daily Total (Non-work) Trip VMT

\begin{tabular}{|c|c|c|c|c|c|c|c|c|}
\hline & \multicolumn{4}{|c|}{ (1) OLS 2001} & \multicolumn{4}{|c|}{ (2) OLS 2009} \\
\hline Trip Туре & $\begin{array}{l}\text { Other member } \\
\text { Telecommuting } \\
\text { (dummy) }\end{array}$ & t-value & $\begin{array}{c}\text { number } \\
\text { of obs }\end{array}$ & R-sq & $\begin{array}{l}\text { Other member } \\
\text { Telecommuting } \\
\text { (dummy) }\end{array}$ & t-value & $\begin{array}{c}\text { number } \\
\text { of obs }\end{array}$ & R-sq \\
\hline Total Nonwork Trips (log) & 0.043 & $(0.84)$ & 25,786 & 0.046 & 0.029 & $(0.92)$ & 78,965 & 0.060 \\
\hline Shopping Trips (log) & 0.060 & $(0.91)$ & 15,272 & 0.032 & -0.043 & $(-1.07)$ & 46,868 & 0.040 \\
\hline $\begin{array}{l}\text { Other Family/Personal } \\
\text { Business Trips (log) }\end{array}$ & 0.034 & $(0.46)$ & 10,870 & 0.027 & 0.049 & $(1.04)$ & 31,865 & 0.032 \\
\hline School/Church Trips (log) & -0.045 & $(-0.50)$ & 4,316 & 0.078 & 0.080 & $(1.16)$ & 10,311 & 0.088 \\
\hline Medical/Dental Trips (log) & 0.261 & $(1.58)$ & 2,732 & 0.088 & $0.226 * *$ & $(2.33)$ & 10,577 & 0.081 \\
\hline $\begin{array}{l}\text { Visit Friend/Relatives Trips } \\
\text { (log) }\end{array}$ & -0.065 & $(-0.52)$ & 5,183 & 0.025 & 0.042 & $(0.46)$ & 13,939 & 0.027 \\
\hline $\begin{array}{c}\text { Other Social/Recreational } \\
\text { Trips (log) }\end{array}$ & -0.056 & $(-0.75)$ & 11,438 & 0.035 & -0.023 & $(-0.51)$ & 36,386 & 0.036 \\
\hline
\end{tabular}
t-statistics in parentheses

$* * * \mathrm{p}<0.01, * * \mathrm{p}<0.05, * \mathrm{p}<0.1$

1. For all models, control variables include age, male, medical condition, education, household income (log), child, number of vehicles per driver, residence in urbanized area, residence in rural area, not in a MSA, in a MSA of 250000-499999, in a MSA of 500000-999999, in a MSA or CMSA of 1-2 millions, In a MSA or CMSA over 3 millions or more, weekend.

2. Coefficient estimates for all control variables are not shown.

3. The telecommuting dummy variable used is whether the non-worker has other household members telecommuting.

4. The sample is restricted to non-workers who used personal vehicles in these non-work trips.

5. Dependent variables have taken log transformation. 


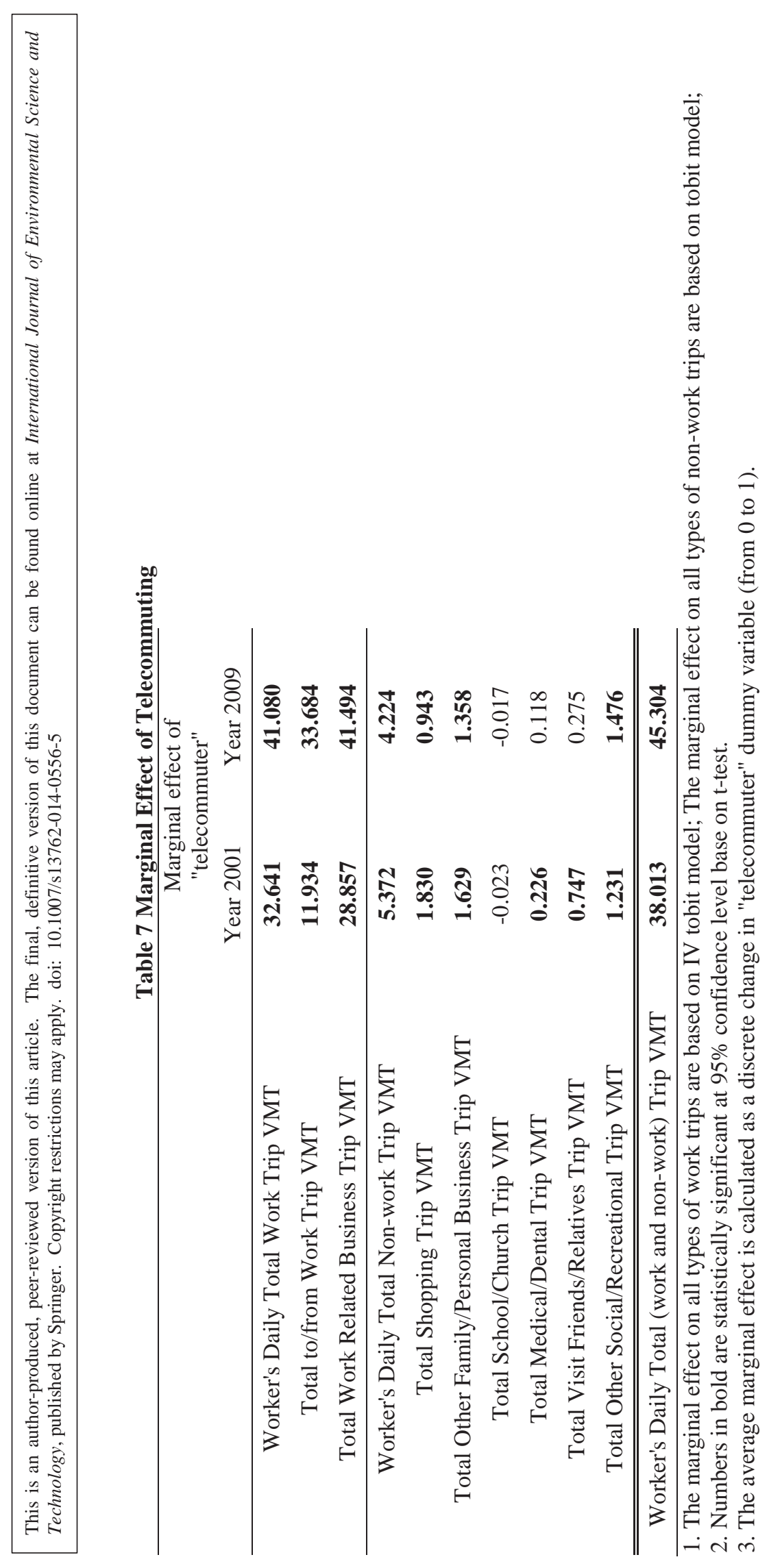



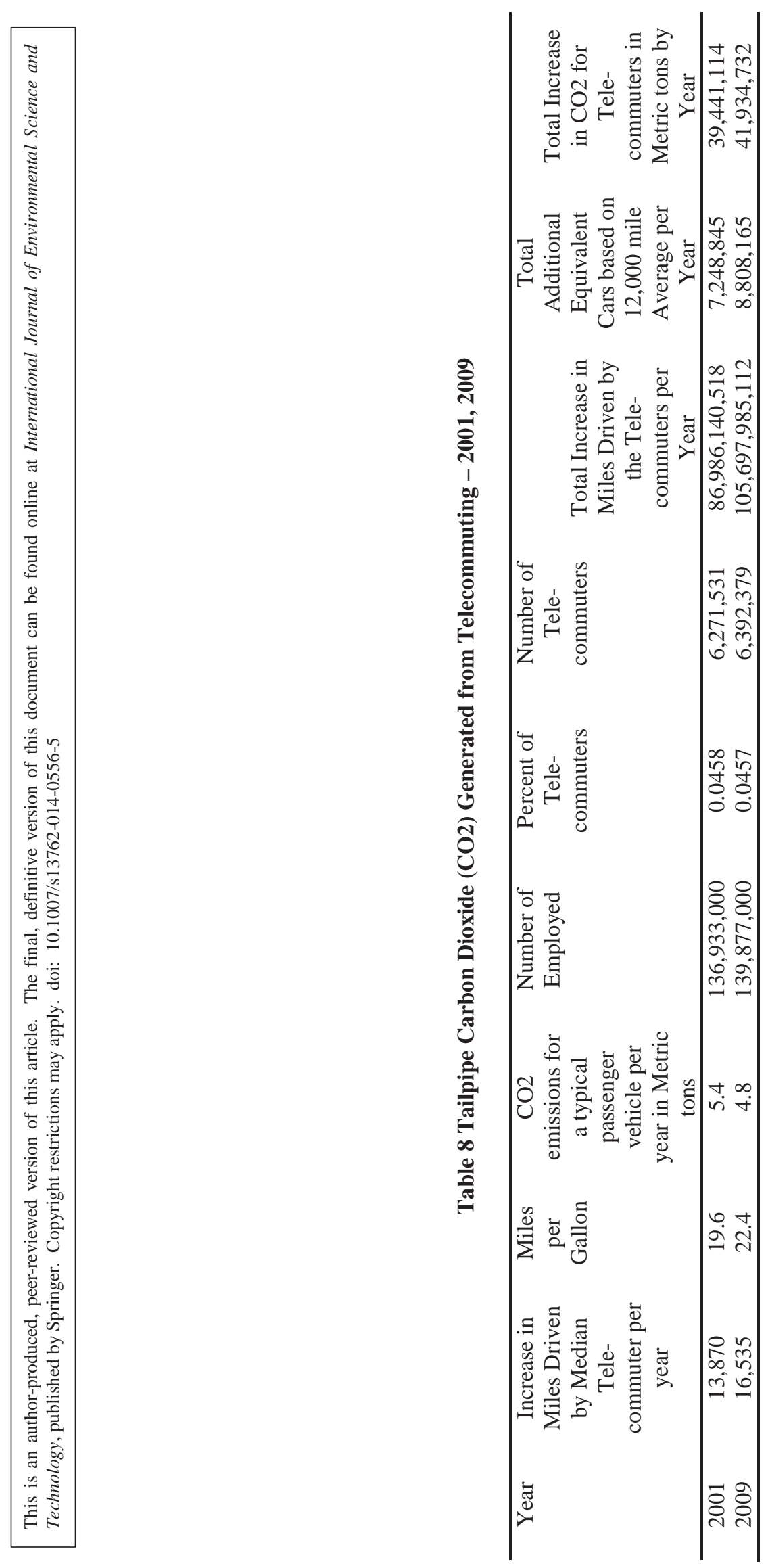